Hydrol. Earth Syst. Sci. Discuss.,

https://doi.org/10.5194/hess-2017-364-RC2, 2017

(c) Author(s) 2017. This work is distributed under

the Creative Commons Attribution 4.0 License.
Hydrology and

\title{
Interactive comment on "Hydraulic
}

characterisation of iron oxide-coated sand and gravel based on nuclear magnetic resonance relaxation modes analyses" by Stephan Costabel et al.

\section{Zhang (Referee) \\ chizhang@ku.edu}

Received and published: 5 October 2017

The comment was uploaded in the form of a supplement:

https://www.hydrol-earth-syst-sci-discuss.net/hess-2017-364/hess-2017-364-RC2-

supplement.pdf 